\title{
Role of Local Government in Indigenous Market Management in the Rural Areas of Bangladesh: Do These Markets Play Development Roles?
}

\author{
Ziauddin Ahmed \\ Senior Assistant Secretary (OSD on study) \\ Ministry of Establishment, Govt. of People's Republic of Bangladesh \\ Student of Master of Public Policy and Management, The University of Melbourne, Australia \\ Former UNO, DoaraBazar Upazila of Sunamganj District of Bangladesh
}

\begin{abstract}
Hat-Bazars are the indigenous markets that work under the supervision of Local Government and owned by the Local Government in Bangladesh. These markets play vital role for the development in the rural areas of Bangladesh. But, there are challenges for proper management of the markets. Hat-Bazar under local government has the following characteristics:

1) It has legal entity under Local Government bodies and formed through an act of legislature named The State Acquisition and Tenancy Act, 1950.

2) It helps the local Government bodies to earn revenue and maintenance expenses.

3) Local businessmen and farmers can market their products and crops in these Hat-Bazars.

4) Central Government also earns revenue getting the land tax, VAT, income tax from the Hat-Bazars.

This article is written based on a study. Objectives of the study were to learn the lease procedure of Hat-Bazar (Local Govt. Markets), to identify the strengths, weaknesses, opportunities, and threats of Hat-Bazar and to analyze the Hat-Bazar management under Upazila Parishad and Pourashava and to find out the ways for augmenting their income and its efficient and effective utilization. . In respect of any particular reference the study was confined to the local government bodies of rural areas only. This study focused on the scheduled government markets (Hat-Bazar) of rural areas (Municipality and Upazila) only, but there were unauthorized markets in Govt. owned land also. Those markets were not taken into considerations. Depth interview method with structured questionnaire was adopted. A total number of 240 persons were interviewed. The interviewees comprised of cross-section of people including public representatives, Govt. officials, businesspersons, lessee and NGO workers. Observations and focus group discussion methods were taken into account also. Secondary sources of data were also included.
\end{abstract}

Existing policy for the management of indigenous markets (Hat-Bazar) was reviewed for the study.

Analyzing the responses of the respondents, collected data and observations following recommendations could be summarized:

1) Political interference should be stopped to make the local Govt. bodies effective and active.

2) Proper maintenance, sanitation and infrastructure should be ensured to make the govt. Hat-Bazar effective.

3) Political interference and administrative control should be avoided to make the Hat-Bazar committee effective. Businesspersons should get priority in Hat-Bazar management.

4) Hat-Bazar management policy should be made more understandable.

5) Lease should be ensured and direct collection should be avoided in order to increase revenue.

6) Leasing procedure should be made easy and should be done in short period.

7) Share of Upazila and Union Parishad and Municipality from Hat-Bazar should be increased.

8) Hat-Bazar management activities should be done in Upazila level.

9) Union Parishad may be given full authority to manage all Hat-Bazars up to a certain pecuniary limit.

10) Women marketers should get proper security and sitting arrangements.

11) Law and order situation should be maintained in Hat-Bazar. 
12) The Hat-Bazar management committee should arrange special transportations for the businessperson so that they can carry their products in appropriate price.

Government Hat-Bazars are the main indigenous markets of Bangladesh. From the very ancient period these markets are the only places where farmers and producers can sell their products. These markets control the local business as well as the national business. So, environment, infrastructure, and, law and order of these markets should be maintained properly. The Hat-Bazar management committees can ensure these with the help of local administration and the local Govt. authority. If proper management is ensured these indigenous markets could be able to aid the development of Bangladesh.

Keywords: Bangladesh, Rural areas, Hat-Bazar, Indigenous markets, Development role, Challenges

\section{Background}

Indigenous markets popularly known as Hat-Bazars work under the supervision of Local Government and owned by the Local Government in Bangladesh. Duane Lockard defines local government as "a public organization authorized to decide and administer a limited range of public policies within a relatively small territory which is a sub-division of a regional or national government". This definition doesn't take into account the financial and legal status of local government and it doesn't specify its representative character. The UN definition is rather comprehensive. It defines local government as "Local government refers to a political sub-division of a nation or state which is constituted by law and has substantial control of local affairs, including the power to impose taxes or exact labor for prescribed purpose. The governing body of such an entity is elected or otherwise locally selected". The Encyclopedia of Social Sciences defines local government as "The government, which has a territorial non-sovereign community having/ possessing the legal right and the necessary organization to regulate its own affairs". The Report of the Indian Statutory Commission of 1930 defines local government as "A representative organization, responsible to a body of electors, enjoying wide powers of administration and taxation, and functioning both as a school for training and a vital link in the chain of organizations that make up the government of the country". Whatever the definition may be the local government, the Hat-Bazar under local government has the following characteristics:

1) It has legal entity under Local Government bodies and formed through an act of legislature named The State Acquisition and Tenancy Act, 1950.

2) It helps the local Government bodies to earn revenue and maintenance expenses.

3) Local businessmen and farmers can market their products and crops in these Hat-Bazars.

4) Central Government also earns revenue getting the land tax, VAT, income tax from the Hat-Bazar.

\section{Objectives of the study}

The objectives of the study are:

1) To evaluate the functions of local Govt. (Upazila Parishad, Union Parishad and Pouroshava) in Hat-Bazar management in the rural areas of Bangladesh and their present development roles based upon the respondents' opinion towards effective, efficient and people oriented Hat-Bazar management.

2) To learn the lease procedure of Hat-Bazar (Indigenous Markets).

3) To identify the strengths, weaknesses, opportunities, and threats to Hat-Bazar management.

4) To analyze the Hat-Bazar management under Upazila Parishad and Pourashava and to find out the ways for augmenting their income and its efficient and effective utilization.

5) To know the role of Govt. Hat-Bazar in income generation for women, businesspersons and farmers.

\section{Research Methodology}

This research is mainly a qualitative study, based on both primary and secondary sources of data. Both primary and secondary sources of data have been collected.

To collect primary data in-depth interview with semi-structured questionnaire has been followed. The interviewees comprised of cross-section of people including people's representatives to the local government bodies, government official and staffs, businesspersons, lessee and NGO workers. Total number of interviewees was 240.

To get the idea of Hat-Bazar management procedure and rules as well as to know the opinions, focus group discussion with the public representatives, Govt. employee, and businesspersons has been carried out. Observations also have been carried out.

This study is focused on the scheduled government indigenous markets (Hat-Bazar) of Narayangonj Sadar Upazila and Narayangonj Pourashava (Municipality), Chhatak Upazila and DoaraBazar Upazila of Sunamganj district areas of 
Bangladesh only, but there were unauthorized markets in Govt. owned land also. Those markets have not been taken into considerations.

The secondary source includes registers, books, journals, government gazettes, government circulars, government publications etc.

\section{Concept of Hat-Bazar}

Hats are the Govt. controlled markets with no permanent or semi-permanent shops but holding Hats daily or once or twice a week where only squatters assemble on fixed days.

Bazars are Govt. controlled markets with permanent or/and semi-permanent shops holding daily or once or twice a week where vendor squatters.

\subsection{Classification of Govt. Hat-Bazar (Indigenous Markets)}

There are generally two classes of Government hats and markets.

1) Markets with permanent or/and semi-permanent shops holding daily or once or twice a week where vendor squatters, i.e., causal vendors who have no permanent or semi-permanent shops display their goods on roadsides or in Hat-stalls or in the open space (Tohabazar) of the market place.

2) Markets with no permanent or semi-permanent shops but holding Hats daily or once or twice a week where only squatters assemble on fixed days.

\subsection{Establishment of new Hat-Bazar}

According to the Government Estate Manual, 1958 to establish Hats and Bazars (Markets) the below mentioned rules may be followed:

1) Hats and Bazars (Markets) may be established in the Government Estate where there is demand for these to suit the convenience of the public. Where there are suitable Hats in existence for a long time in the neighbourhood, there is no need to establish a new one in its vicinity.

2) In making a new settlement of waste char or accreted lands it is desirable to make provision for Hats. No new Hat except in isolated and remote areas should be established which does not promise to financially profitable.

\subsection{Procedure to establish new Hat}

When submitting proposals for the establishment of a new Hat, the collector (Deputy Commissioner) should estimate:

i. Cost of preparing the site.

ii. Cost of construction of shops and sheds.

iii. Receipts expected from the Hats, salami and rent separately.

iv. Cost of arrangement, recurring expenditure on account of maintenance, repairs, and establishment.

v. Cost of construction should be met out of the grant for improvement of Government Hats.

\subsection{Leasing Procedures of Government Hat-Bazar:}

\subsubsection{Lessor}

Upazila Nirbahi Officer of the concern Upazila will reserve the jurisdiction to lease out the Hat-Bazar under the geographical area of the Upazila.

Concern Municipality/City corporation authority will lease out the Hat-Bazars under its geographical area.

\subsubsection{Lease process:}

Lease activities shall be commenced in the month of Bangla (Bengali) month Magh of the year prior to the lease year preparing a complete calendar of lease activities. Deputy Commissioner and the local govt. department must provide the calendar.

Hat-Bazar shall be leased out for one year according to the Bangla year. Lease process shall be completed by the Bangla month of Chaitra.

Expenditures for lease process shall be met from the lease money of Hat-Bazar.

\subsubsection{Tender Process:}

(a) Sealed bid will be invited for each lease case of Govt. Hat-Bazar. All the bids will be accompanied by $20 \%$ of total quoted price by bank draft. $15 \%$ of total quoted price will be adjusted with the lease money and rest $5 \%$ will be reserve as earnest money. The earnest money will be declared forfeited if the lessee fails to maintain the Hat-Bazar properly or 
do any harm to existing infrastructures. Otherwise at the end of the year the earnest money will be refunded in favour of the lessee.

(b) The money earned by selling the tender schedule will be considered as the revenue income of municipality and for Upazila it will be deposited in development fund.

(c)Following steps will be taken to make tender schedule and form available:

Tender forms shall be collected from the following offices.

i.e. Forms of Hat-Bazar controlled by Upazila Nirbahi Officer shall be available in his/her office, Assistant Commissioner (Land) office, Police station, Sonali Bank, DC office.

Tender schedule of Hat-Bazar under municipality authority shall also be collected from concern municipality office.

(d)At least 15 days before the submission date of the bids the tender schedule shall be properly advertised in the Hat-Bazar, in important Govt. and private offices using mikes, posters and using the notice boards. If the expected lease value is between 2 lac taka to 25 lac taka then tender schedule shall be published in local newspaper and if the value is more than 25 lac taka it must be published in national newspaper.

(e)Bids shall be submitted in office of the UNO or DC office or AC (Land) Office.

(f) Highest quotation price of the bids will be accepted and if the amount is less than that of average of the preceding 3 years then re-tender will be declared.

The re-tender process will be continued until attaining the expected price. If the Bengali New Year begins then the steps for direct collection (Khas collection) will be taken.

(g)Activities for direct collection (Khas collection):

Hat-Bazar under Upazila Parishad: An eight member committee for Hat-Bazar controlled by Upazila Nirbahi Officer will be headed by him/her and AC (Land), concern UP chairman and UP members of concern ward; DC's representative shall be the members.

Hat-Bazar under Pourashava: Hat-Bazars under municipality will be headed by the Chief Executive Officer/Municipality (Pourashava) chairman of municipality and there shall be 5 members.

The committee can appoint manpower for khas (direct) collection.

The committee can meet its expenditure during activities from the collections and it cannot be more than $5 \%$ of the collected money.

If any Hat-Bazar leased out during the direct collection period the payable will be, the amount got deducting the direct collected money from the total lease money.

If the lessor fails to transfer the possession to the lessee due to legal restriction or the lessee is compelled to remain off raising the toll, the lessor has to pay out the proportional ratio of lease in favour of the lessee.

(h) Lease decision should be made prompt adopting the following processes:

Upazila Nirbahi officer, with his/her opinion will present a comparative statement of the submitted bids before the Upazila development and coordination committee within 3 working days. The committee will convey the decision within 7 working days.

The comparative statement of submitted bids will be published for all.

i) For municipality the sealed bids shall be submitted to either DC office or to municipality office. DC will send the comparative statement of submitted bids to the Municipality Chairman. CEO of municipality will consolidate all the bids submitted to both DC office and municipality office and will present before the municipality tender committee within 3 working days. After sorting out the bids in committee the bids shall be presented accompanied by the opinion of the committee before the chairman for approval within 2 working days. The chairman will give his/her consent within 2 working days.

j) Same procedures will be followed for City Corporation also.

k)If it is indispensable to change the date of bid submission then Mayor/Chairman, or Deputy Commissioner or UNO or his/her representative will declare the next date and time in written. Successful bidders will be informed within 3 days from the date of approval and the bidder will deposit the rest amount of the lease money within 7 days being informed. Otherwise his/her bid will be declared void and the earnest money will be forfeited. Forfeited money will be deposited as the revenue income. After depositing all the lease money in Govt. fund the lessee makes covenants with the lessor.

1) UNO will send a statement of lease money to the Deputy Commissioner within 15 days of leasing out the Hat-Bazar and he/she will send a comparative statement of lease money of last 3 years to the local Govt. division. 
m) The lease money earned from the Hat-Bazar will be deposited in a bank account names 'Income from Hat-Bazar lease'. The revenue earned will be distributed among different sectors.

n) Deputy Director of local govt. will be a member of municipality tender committee.

\subsection{Appeal/Disposal of Appeal}

(a) If there is any grievance about the Hat-Bazar lease, the written grievance shall be submitted to the next higher authority within 7 working days after the approval of the bid. The DC will hear the grievance about the UNO's and 'B','C' grade municipality authority's decision and he/she will pass a decision. For any grievance about DC's decision the Divisional commissioner will hear and give a decision. The local govt. division will hear the grievance against the divisional commissioner.

(b) UNO/Municipality Chairman or DC/CEO or their representative will sign the covenant of lease.

(c) The lessee will sign the covenant and that will be according to the form prescribed in The Land Management Manual, 1991.

(d) The lessee will keep the Hat-Bazar clean on regular basis.

(e) DC for Upazila, Divisional Commissioner for municipality will prepare and approve a toll chart for different commodities. The lessee must place the toll chart in a visible place; otherwise the lessor may cancel the covenant.

(f) The lessee cannot lease out the Hat-Bazar to another person or cannot give sub-lease. In any case if this event takes place the lease treaty will be voided.

\subsection{Distribution of lease money earned from the Hat-Bazar}

(a) Lease money of Hat-Bazar leased out by UNO will be distributed as follows:

i. 5\% of Lease money after deducting the expenditure will be deposited in Govt. fund as '7-land revenue' within 7 working days.

ii. $20 \%$ of that money will be deposited for the salary of UP secretary and staffs in '4-deposit from Hat-Bazar lease' under '7-land revenue' within 7 working days.

iii. $15 \%$ of that money will be spent for the maintenance and development for respective Hat-Bazar under the approval of Upazila development coordination committee. For the routine and periodical maintenance of Hat-Bazar this expenses might be risen up to $25 \%$.

iv. $10 \%$ of the money will be spent for all the Hat-Bazars under the Upazila.

v. $5 \%$ of the money will be given to that Union Parishad in additional where the Hat or Bazar is situated.

vi. Rest $41 \%$ money will be deposited in Upazila development fund. This money will be distributed proportionately among the Unions as $40 \%$ according to the population size, $40 \%$ according to the geographical area and $20 \%$ according to the underdevelopment.

vii. The Muktijoddha Sangsad will get $4 \%$.

(b) Lease money of Hat-Bazars leased out by City corporation/Municipality will be distributed as follows:

i. 5\% of Lease money after deducting the expenditure will be deposited in Govt. fund as '7-land revenue' within 7 working days.

ii. $45 \%$ of that money will be spent for development and maintenance of the Hat-Bazar under that Municipality/City Corporation.

iii. Rest 50\% will be considered as the revenue income of Municipality/city Corporation.

\subsection{Deputy Commissioner's responsibility on Hat-Bazar}

In addition to the responsibilities mentioned in policy the DC will establish new Hat-Bazar, evict illegal markets, and demark the periphery of the markets according to the Land Management Manual, 1991.

The Hat-Bazars that are not identified according to this policy, if need to hold on the eve of Eid or any other festival then the concern UNO/Municipality Chairman with the prior permission of the DC will lease out following the rules. $20 \%$ of the Lease money will have to be deposited within 7 working days .Rest $80 \%$ of lease money will be deposited in Municipality fund or Upazila development fund.

\section{Hat-Bazar Management Committee}

Management committee will be formed for each of the Hat-Bazar for regular operations, maintenance, collections and for the development of the concern Hat-Bazar. In Upazila level Upazila Hat-Bazar Management committee will be 
formed for directing, supervising and advising the Hat-Bazar Management committees .The DC will form the Upazila Hat-Bazar Management committee and the UNO will form the concern Hat-Bazar Management committee.

\subsection{Hat-Bazar based Management Committee:}

\subsubsection{Composition:}

The composition of each of the Hat-Bazar Management Committee will be as follows:

i. The president will be the Union Parishad(UP) Chairman of the concern UP.

ii. One member will be elected among the shopkeepers of all the permanent shops of the concern Hat-Bazar.

iii. Union member of the concern ward will be a member.

iv. Woman (Reserved) Union Parishad member of the concern ward will be a member.

v. Union land Assistant Officer of the concern UP will be a member.

vi. One member will be elected/nominated among the women shopkeepers (if any) of the concern Hat-Bazar.

vii. Community organizer of Upazila Engineering office will be a member.

viii. One member will be elected/nominated among the shopkeepers of the entire temporary (operating for at least 6 months) shops of the concern Hat-Bazar.

ix. One member will be elected/ nominated among the rickshaw and van puller of the concern Hat-Bazar.

$\mathrm{x}$. The bus/truck owners association will nominate one member.

xi. The shopkeepers of all the permanent shops will elect a member among themselves as the member secretary of the concern Hat-Bazar.

- $\quad$ No lessee can be the member of the committee.

\subsubsection{Responsibilities:}

i. To chalk out the yearly development and maintenance plan of the concern Hat-Bazar based on the reserved money of the lease money and to submit the plan to the authority.

ii.To supervise the toll collection and the collectors.

iii. To resist the excess toll collection.

iv. To resist the illegal toll collection, extortions, etc.

v. To keep the Hat-Bazars clean and ensure sanitation.

vi. To arrange at a meeting each month and submit the recommendations to the Upazila Hat-Bazar committee.

vii. To facilitate the women seller and buyer for transactions.

\subsection{Upazila Hat-Bazar Management Committee}

\subsubsection{Composition:}

Upazila Hat-Bazar Committee will be formed as follows:

i. UNO will be the president.

ii. Upazila Engineer will be a member.

iii. All the Union Parishad chairmen of the Upazila will the members.

iv. One distinguished person will be a member (nominated by the DC).

v. One Govt. officer of the Upazila will be a member (nominated by the DC).

vi. Two of the presidents of all of the Hat-Bazar committees will be the members (nominated by the UNO).

vii. AC (Land) will be the member secretary.

\subsubsection{Responsibilities:}

i. The committee will sit for meeting at least once in a month.

ii. To supervise proper management, operation and maintenance of the all Hat-Bazars of Upazila.

iii. To approve the development and maintenance plan submitted by the Hat-Bazar management committees.

iv. To ensure the regular meeting of Hat-Bazar management committees.

v. To supervise the activities of the Hat-Bazar management committees. 
vi. To inform the DC about the activities of the Hat-Bazar management committees and Upazila Hat-Bazar management committee.

vii. To ensure the toll collection according to the toll chart.

viii. To maintain law and order in Hat-Bazars.

ix. To resist illegal occupations.

\subsection{Municipality (Pourashava) Hat-Bazar Management Committee}

\subsubsection{Composition:}

i. Municipality Chairman/Administrator will be the chairperson.

ii. Deputy director of local Govt. of DC office will be a member (for 'A' category municipality only).

iii. Upazila Engineer will be member (for municipality under Upazila).

iv. Two Govt. officers of the Upazila will be the members (nominated by the DC).

v. All the ward commissioners of the concern municipality will be the members.

vi. Two distinguished persons of the municipality will be the members (nominated by the DC).

vii. One teacher of the schools/colleges of the municipality area will be a member.

viii. Two shopkeepers/businesspersons of the each Hat-Bazar under the municipality will be the members.

ix. Executive Engineer/ Assistant Engineer of the municipality will be a member.

$\mathrm{x}$. The Chief Executive Officer (CEO)/the secretary of the concern municipality will be the member secretary.

\subsubsection{Responsibilities:}

i. To chalk out the development plan and implement those with the approval of the DC.

ii. To supervise the toll collection and the collectors.

iii. To resist the excessive toll collection.

iv. To resist the illegal toll collection, extortions, etc.

v. To ensure law and order of the Hat-Bazar.

vi. To keep the Hat-Bazar clean and ensure sanitation.

vii. To resist illegal occupation.

viii. To make necessary toilet/latrine in each Hat-Bazar.

ix. The committee will sit for meeting at least once in a month.

\section{SWOT Analysis}

SWOT is an acronym, which stands for Strength, Weaknesses, Opportunities, and Threats of an approach, a system, or an organization in achieving its goals and objectives. After analyzing the policy, activities of different Hat-Bazar management committees and the opinions of various cross sections of people, the SWOT analysis of Hat-Bazar could be done as follows:

\subsection{Strengths:}

- Participation of farmers and businessperson.

- Revenue generation.

- Proper utilization of govt. land.

\subsection{Weaknesses:}

- Political interferences.

- Administrative control.

- Inefficiency, Corruption and illiteracy of the elected representatives.

- Weak organizational structure.

- Absence of coordination.

\subsection{Opportunities:}

- Strengthening local government.

- Ensure women participation. 
- Infrastructure development.

- $\quad$ Proper Land management.

6.4 Threats:

- $\quad$ Private markets.

- Illegal occupations.

- Middleman/brokers.

- Law and order situation.

\section{Findings of the study: Development roles of indigenous markets}

The indigenous markets can not play development roles properly as there are number of challenges for the effective management of these markets. Those challenges are various and those are the outcomes of the study. According to the primary and secondary data collected and observations, findings of the study are as follows:

\subsection{Local Government system in grassroots level is not working properly}

Local Govt. system in grassroots level is not working properly due to political interferences. Generally the big political parties support the public representatives of local Govt. bodies. Inefficiency is also a reason along with other reasons. There is lack of coordination in many of the Union Parishad and Pourashava as well as Upazila Parishad. In order to ensure good governance in grassroots level the local Govt. should work independently.

\section{$<$ Figure 1>}

\subsection{Hat-Bazars under Local Govt. bodies are not functioning properly}

The Govt. Hat-Bazars controlled by the local Govt. authority are not functioning properly due to mainly the political interference. In many of the Union Parishad and Pourashava the Hat-Bazar management committees have not been formed till today. Generally political leaders rule the management of the Govt. markets that ultimately politicized the management. Absence of Hat-Bazar maintenance and absence of coordination also hamper the proper function of the Hat-Bazar.

\subsection{Area of the Hat-Bazar is small}

The area of the Hat-Bazar is too small to meet the peoples' need. Somewhere the size of the Hat-Bazar is accurate, but expansion is required.

\section{$<$ Figure 2>}

\subsection{Present Hat-Bazar management policy is not sufficient}

Hat-Bazar management policy is not sufficient although Govt. employees think it is sufficient. It is not sufficient due to complex leasing policy, excessive administrative control and improper coordination.

\section{$<$ Figure 4>}

\subsection{Hat-Bazar leasing procedure is not satisfactory}

Hat-Bazar leasing procedure is not satisfactory as it is tedious and administrative control is there.

\subsection{Businesspersons in Govt. Hat-Bazar face different problems}

In govt. Hat-Bazar the businesspersons faces different problems and the major problem is the involvement of the middlemen. The middlemen collect money from the businesspersons and control the markets. There are also other problem like transportation, security and sanitation problems. In observations it is found that the business space in Hat-Bazar is narrow and the environment is unhealthy. Sanitation system is absent there.

\subsection{Hat-Bazar management committees don't work properly}

Hat-Bazar management committees do not work properly due to mainly political interference, because the local leaders of the political parties control most of the management committees. There are also other reasons like absence of toll chart, ineffectiveness, poor maintenance, and poor coordination.

\subsection{Hat-Bazar fulfill peoples' need, but not very much}

The Govt. Hat-Bazar doesn’t fulfill peoples' need very much, but fulfill much or not too much. People expect to market their product without any hassle, which the Hat-Bazar cannot ensue. Both sellers and buyers want terrorism free clean environment in Hat-Bazar that is generally absent in govt. Hat-Bazar. Poor infrastructures are also a great disadvantage of Hat-Bazar. Less women participation is also a problem. 


\subsection{Less women participation in Hat-Bazar}

In govt. Hat-Bazar the female marketers cannot participate too much .The security measure can ensure their participation. Female marketers need toilets and sheds in the markets.

\section{$<$ Figure 3>}

7.10 Union Parishads should get proper share from the Hat-Bazar revenue.

According to the present rule the Union Parishads get 5\% of the revenue of each Hat-Bazar. But almost they don't get the proper share. Moreover most of respondents think it should be more than 5\%.

\subsection{Upazila Parishad sometimes doesn't get the proper revenue from Hat-Bazar}

Upazila Parishad sometime doesn't get the proper share from Hat-Bazar due to syndicated competitions in tender. Poor infrastructures of the Hat-Bazar are other reasons, as Upazila Parishad has to maintain that. Corruption and inefficiency are also the reasons.

\subsection{Highest portion of the revenue should be spent for maintenance.}

Govt. Hat-Bazars are created to facilitate the people, so the Hat-Bazars should be maintained properly and highest part of the earned revenues should be spent for that.

\subsection{Lease is the best way to collect revenues}

To collect revenue from Hat-Bazars lease is the best process that ensures the revenue earnings. There are other processes also, but lease out processes ensure maximum revenue earnings. In the case of direct collection it is found that the revenue earning decreases.

\section{$<$ Table 1>}

\section{$<$ Table 2>}

$<$ Table 3>

\section{$<$ Table 4>}

\subsection{Revenue can be augmented by improving the infrastructures}

By improving the infrastructures of the govt. Hat-Bazars the revenue earnings can be increased. If infrastructures are improved then more buyers and sellers will participate and the lessee may earn more. Full authority to manage all Hat-Bazars up to a certain pecuniary limit can also ensure that, because the local govt. bodies can help the lessee for improvement of the infrastructure and management.

\subsection{Hat-Bazar management activities should be done at Upazila level}

Earlier Hat-Bazar management activities took place in district level and the DC used to do that. Later full authority to manage all Hat-Bazars up to a certain pecuniary limit was given to the Union Parishad for strengthen the local Govt. bodies. After that, this authority was withdrawn due to corruption and inefficiency. Presently Upazila Parishad and Pourashava are doing the activities that are running successfully.

\subsection{The farmers and businesspersons do not get the proper price in Hat-Bazars}

In most of the cases the farmers and businesspersons do not get the proper price of their products or they somewhat get proper price. The main impediment behind not getting the proper price is the role of middlemen.

\subsection{Private markets and illegal occupation are the main threat to govt. markets}

In most of the cases the illegal occupants capture the land Govt. Hat-Bazar as well as the roadside, riverside and establish illegal markets. These markets discourage the sellers and buyers to participate in govt. Hat-Bazars. Modern private markets also attract the marketers which may cause less participation in govt. markets.

\section{Conclusions}

Government Hat-Bazars are the main indigenous markets of Bangladesh. From the very ancient period these markets are the only places where farmers and producers can sell their products. These markets control the local business as well as national business. So, environment, infrastructure and, law and order situation of these markets should be maintained properly. The Hat-Bazar management committees can ensure these issues with the help of local administration and the local Govt. institutions.

Effective Hat-Bazar management can ensure local development from these markets. Some recommendations can be delivered for effective Hat-Bazar management. Analyzing the responses of the respondents and the observations following recommendations can be summarized:

1) Political interference should be stopped to make the local Govt. bodies effective and active. 
2) Proper maintenance, sanitation and infrastructure should be ensured to make the govt. Hat-Bazar effective.

3) Political interference and administrative control should be avoided to make the Hat-Bazar committees effective.

4) Businesspersons should get priority in Hat-Bazar management.

5) Hat-Bazar management policy should be made more understandable.

6) Lease should be ensured and direct collection should be avoided in order to increase revenue

7) Leasing procedure should be made easy and should be done in short period.

8) Share of Upazila Parishad, Pourashava and Union Parishad from Hat-Bazar revenue earnings should be increased.

9) Hat-Bazar management activities should be done in Upazila level.

10) Union Parishad may be given full authority to manage all Hat-Bazars up to a certain pecuniary limit.

11) Woman marketers should get proper security and sitting arrangements

12) Law and order situation should be maintained in Hat-Bazars.

13) The Hat-Bazar management committees should arrange special transportations for the businesspersons, so that they can carry their products in an appropriate price.

14) The law enforcing force should control the activities of the middlemen.

15) Illegal occupants should be evicted from the govt. land.

Hat-Bazars under Local Govt. bodies are not functioning properly, as the local govt. bodies do not have the authority. To fulfill peoples' need the policy should be made sufficient. Illegal occupants should be evicted. Accountability of the management personnel should be ensured. If the market management committees work properly then people will be benefited and local Govt. bodies will earn revenue in a huge scale, which ultimately ensures local development.

\section{References}

Ahmed, Ali. (1984). "Bangladesh Publication and Senior Civil Servants", BASF, Dhaka.

Alam, Shohidul et al. (2000). "Readings in Law and Administration", BCS Admin Academy, Dhaka.

Alam, Bilquis Ara, et al. (1986). "The Ordinances for Rural Local Bodies”, NILG, Dhaka.

Alam, Bilquis Ara, et al. (1987). "Union Parishad Manual", NILG, Dhaka.

Ali, Sheikh Maqsood, et al. (1983). "Decentralization and People’s Participation in Bangladesh", NIPA, Dhaka.

Ali, Qazi Azher. (1978). "District Administration in Bangladesh", NIPA.

Chowdhury, Aditee Nag. (1996). "Let Grassroots Speak”, UPL, Dhaka.

Chowdhury, Md. Hedayetul Islam et al. (1991). "Collectorate Proshashanik Binnash".

Faizullah, Md. (1987). Development of Local Government in Bangladesh”, NILG, Dhaka.

Government Estate Manual, 1958 published by Pakistan Government.

Hats and Bazars (Establishment) Acquisition Ordinance, 1959.

Hoque, A.N.Shamsul. (1970). "Administrative Reforms in Pakistan", NIPA, Dhaka.

Hyder, Yusuf. (1989). "Development the Upazila Way”, Abdur Rahim Azad.

Hye, Hasnat Abdul. (1990). "Palli Unnayan", Pallab Publishers.

Jahangir, A.K.M. et al. (2000). "Math Prashashon”, Mrs. Hosne Ara Begum, Dhaka.

Khaliquzzaman, A.R.M. (1995). "Zila Prashashon Bangladesh”, Published by the Writer, Dhaka.

Mia, Md. Abdul Kader. (1992). "Adhunik Proshan Babosthapana”, A.K. Pokashani.

Mia, Md. Firoz. (1989). "Union Parishad Bidimala”, Naimur Rahman Chowdhury, Dhaka.

Mia, Md. Firoz. (1990). "Zila Parishad, Palli Parishad O Pourashava Ain”, Khainul Bashar Sabuj, Dhaka.

Morshed, Mahbubur Rahman. (1986). "Bangladesher Civil Service”, Khosroz Kitab Mahal, Dhaka.

Muhith, A.M.A. (1968). The Deputy Commissioner in East Pakistan", NIPA.

Sabuj, Saifur Rashid. (2001). "Local Government (UP) Ordinance, 1983; Local Government (Gram Parishad) Act, 1997; and other Acts", Sams Publication.

Saha, Dilip Kumar. (1999). “Local Government (Union Parishad) Management”, Moitree Saha.

Saha, Dilip Kumar. (1999). "Sthanyo Sarkar-Pourashava Ain O Bidhi”, Moitree Saha, Noakhali. 
Siddique, Kamal. (1995). "Local Government in Bangladesh”, UPL, Dhaka.

"Smriti Charan: Probin Probashaker Avigotta" (1984), COTA, Dhaka.

“The Jounal of Local Government”. (1998), NILG, Vol 27, No. 2.

“The Journal of Local Government”. (1999), NILG, Vol 28, No. 11.

\section{Notes}

Note 1: Source of Data-UNO, Doarabazar

Note 2: Source of Data - Md. Matiul Islam Chowdhury, UNO, Chhatak

Note 3: Source of Data - AC (Land), Narayangonj Sadar

Note *: Bangla (Bengali) year. Starts on $14^{\text {th }}$ April each year.

\section{Acronyms}

ADC: Additional Deputy Commissioner

BIDS: Bangladesh Institute of Development Studies

BBS: Bangladesh Bureau of Statistics

DC: Deputy Commissioner

FGD: Focus Group Discussion

GOB: Government of Bangladesh

MP: Member of Parliament

NGO: Non-Government Organization

OSD: Officer on Special Duty

TK.: Taka (Bangladesh currency)

UNO: Upazila Nirbahi Officer

UP: Union Parishad

UZP : Upazila Parishad

ZP: Zila Parishad

Glossary of Bengali Terms

Baishakh: $1^{\text {st }}$ Month of Bangla (Bengali) calendar.

Bazar: Indigenous Market for commodities.

Chaitra: Last (12 $\left.2^{\text {th }}\right)$ Month of Bangla (Bengali) calendar.

Char: New land created by accumulating silts in rivers/seas.

Crore: 10 millions.

Gram: Village

Gram Sarkar: Village Government.

Hat: Village Periodic Market.

Khas land: Government Owned Land.

Lac: 1 lac equals to 0.1 million.

Magh: $10^{\text {th }}$ Month of Bangla (Bengali) calendar.

Muktijoddha Sangsad: An Association of the freedom (Liberation War) fighters of Bangladesh.

Parishad: Council.

Pourashava: Municipality.

Salami: Down payment of lease money.

Union: A rural area consisting of some villages.

Upazila: Sub-District. 
Upazila Nirbahi Officer: A civil servant deputed by the government to the UZP as Chief Executive Officer.

Zila: District.

Table 1. Revenue earned from Scheduled Hat-Bazar Under DoaraBazar Upazila of Sunamganj District (Note 1, Note *)

\begin{tabular}{|c|c|c|c|c|c|c|c|}
\hline \multirow{2}{*}{$\begin{array}{l}\text { Serial } \\
\text { Number }\end{array}$} & \multirow{2}{*}{$\begin{array}{l}\text { Name of the } \\
\text { Hat-Bazar }\end{array}$} & \multicolumn{5}{|c|}{ Lease Value } & \multirow[t]{2}{*}{ Remark } \\
\hline & & $\begin{array}{l}1412 * \\
\text { (Taka) }\end{array}$ & $\begin{array}{l}1413^{*} \\
\text { (Taka) }\end{array}$ & $\begin{array}{l}1414 * \\
\text { (Taka) }\end{array}$ & $\begin{array}{l}1415^{*} \\
\text { (Taka) }\end{array}$ & $\begin{array}{l}1416^{*} \\
\text { (Taka) }\end{array}$ & \\
\hline 1 & Baliura Bazar & $5,36,782$ & $10,26,000$ & $10,26,600$ & $10,27,000$ & $15,31,000$ & $\begin{array}{l}\text { Direct Collection } \\
\text { in } 1412\end{array}$ \\
\hline 2 & Dohalia Bazar & $4,02,500$ & $4.05,500$ & $4,21,000$ & $4,22,051$ & $6,50,501$ & -- \\
\hline 3 & Bangla Bazar & $1,42,000$ & $1,46,000$ & $2,06,006$ & $2,10,000$ & $1,90,000$ & -- \\
\hline 4 & Bogla Bazar & $1,47,894$ & 99,350 & $2,40,200$ & $2,41,000 /-$ & $2,00,000$ & $\begin{array}{l}\text { Direct Collection } \\
\text { in } 1412-1413\end{array}$ \\
\hline 5 & $\begin{array}{l}\text { Mohabbatpur } \\
\text { Bazar }\end{array}$ & 23,050 & 23,100 & 24,200 & 24,500 & 25,500 & - \\
\hline 6 & Doara Bazar & 73,100 & 74,200 & 55,000 & 50,000 & 69,600 & -- \\
\hline 7 & Tablai Bazar & 1,679 & 3,100 & 3,550 & 3,600 & 4,000 & $\begin{array}{l}\text { Direct Collection } \\
\text { in } 1412\end{array}$ \\
\hline 8 & $\begin{array}{l}\text { Norsinghpur } \\
\text { Bazar }\end{array}$ & 20,440 & 10,500 & 31,000 & 28,100 & 57,500 & $\begin{array}{l}\text { Direct Collection } \\
\text { in } 1412-1415\end{array}$ \\
\hline 9 & Chairgaon Bazar & 10,525 & 8,800 & 12,000 & 8,000 & - & $\begin{array}{l}\text { Direct Collection } \\
\text { in } 1412-1415\end{array}$ \\
\hline 10 & Nasimpur Bazar & 22,500 & 23,200 & 23,200 & 22,610 & 24,000 & -- \\
\hline 11 & Ambari Bazar & $3,90,100$ & $4,33,000$ & $4,91,000$ & $6,32,000$ & $7,76,600$ & -- \\
\hline 12 & Katakhali Bazar & 7,500 & 8,525 & 10,100 & 10,200 & 12,040 & -- \\
\hline 13 & Shyamol Bazar & 7,100 & 3,795 & 8,250 & 12,500 & 9,500 & $\begin{array}{l}\text { Direct Collection } \\
\text { in 1413-1414 }\end{array}$ \\
\hline 14 & $\begin{array}{l}\text { Bangobondhu } \\
\text { Bazar }\end{array}$ & 2,300 & 2,400 & 3,100 & 3,500 & 3,000 & -- \\
\hline 15 & Biani Bazar & 5,500 & 3,450 & 5,650 & 6,000 & 5,500 & $\begin{array}{l}\text { Direct collection } \\
\text { in } 1413\end{array}$ \\
\hline 16 & $\begin{array}{l}\text { Bhabanipur } \\
\text { Bazar }\end{array}$ & 5,500 & 5,550 & 5,550 & 7,850 & 7,320 & -- \\
\hline 17 & Sripur Bazar & 17,600 & 17,800 & 31,200 & 31,500 & 32,000 & $\begin{array}{l}\text { Direct Collection } \\
\text { in 1412-1414 }\end{array}$ \\
\hline 18 & $\begin{array}{l}\text { Mongolpur } \\
\text { Bazar }\end{array}$ & 6,300 & 6,600 & 7,100 & 7,200 & 7,300 & -- \\
\hline 19 & Tengra Bazar & 13,650 & 14,500 & 14,500 & 15,520 & 21,075 & -- \\
\hline 20 & Eruakhai Bazar & 8,300 & 8,600 & 9,100 & 9,200 & 9,200 & -- \\
\hline 21 & Liakatganj Bazar & $1,45,000$ & $2,11,000$ & $2,55,000$ & $2,85,750$ & $3,08,750$ & -- \\
\hline 22 & $\begin{array}{l}\text { Achhirnagar } \\
\text { Bazar }\end{array}$ & 3,225 & 3,250 & 3,600 & 3,700 & 3,800 & -- \\
\hline 23 & Naillar Bazar & 180 & - & - & - & & Direct Collection \\
\hline
\end{tabular}


Table 2. Revenue earned from Scheduled Hat-Bazar under Chhatak Upazila of Sunamganj District (Note 2, Note *)

\begin{tabular}{|c|c|c|c|c|c|}
\hline \multirow{2}{*}{$\begin{array}{l}\text { Serial } \\
\text { Number }\end{array}$} & \multirow[t]{2}{*}{ Name of the Hat-Bazar } & \multicolumn{3}{|c|}{ Lease Value } & \multirow{2}{*}{$\begin{array}{l}\text { Land Area of } \\
\text { the Market }\end{array}$} \\
\hline & & $\begin{array}{l}1413 * \\
\text { (Taka) }\end{array}$ & $\begin{array}{l}1414 * \\
\text { (Taka) }\end{array}$ & $\begin{array}{l}1415^{*} \\
\text { (Taka) }\end{array}$ & \\
\hline 1 & Jawa Bazar & $62,41,000$ & $68,54,000$ & $68,71,000$ & 10.32 Acre \\
\hline 2 & Borokapan Bazar & -- & -- & --- & -- \\
\hline 3 & Gobindagonj New Bazar & $23,29,999$ & $23,50,000$ & $24,05,000$ & 6.2553 Acre \\
\hline 4 & Dharon Bazar & -- & -- & 90,100 & 1.41 Acre \\
\hline 5 & Pirpur Bazar & -- & 12,350 & 12,450 & 2.1225 Acre \\
\hline 6 & Kalaruka Bazar & 2,460 & 2,500 & 2,800 & 3.21 Acre \\
\hline 7 & Rampur Bazar & -- & -- & --- & -- \\
\hline 8 & Hasnabad Bazar & 4,400 & 4,500 & 4,500 & -- \\
\hline 9 & Bawsha Bazar & -- & 2,550 & 2,650 & -- \\
\hline 10 & Chhanbari Bazar & -- & -- & --- & -- \\
\hline 11 & Islampur Bazar & -- & -- & 1,020 & -- \\
\hline 12 & Chanpur Bazar & -- & -- & --- & -- \\
\hline 13 & Chowmuhuni Bazar & -- & 3,650 & --- & -- \\
\hline 14 & Laxmibaur Bazar & 3,300 & 3,400 & 3,500 & -- \\
\hline 15 & Amertoil Bazar & -- & -- & --- & -- \\
\hline 16 & Aligonj Bazar & 14,000 & 14,500 & 14,600 & -- \\
\hline 17 & Haidarpur Bazar & -- & 2,600 & 2,650 & -- \\
\hline 18 & Lakeshwar Bazar & -- & 25,550 & --- & -- \\
\hline 19 & Bangla Bazar & -- & -- & 810 & -- \\
\hline 20 & Buraiya Bazar & -- & 1,350 & 1,450 & -- \\
\hline 21 & Dolar Bazar & -- & -- & $1,80,000$ & 4.67 Acre \\
\hline 22 & Moinpur Bazar & 7,500 & 9,000 & 9,100 & -- \\
\hline 23 & Zahidpur Bazar & 950 & 1,000 & 1,050 & 0.89 Acre \\
\hline 24 & Ziapur Bazar & 1,600 & 2,500 & 2,600 & 1.77 Acre \\
\hline 25 & Shirajgonj Bazar & -- & 20,500 & 20,600 & -- \\
\hline 26 & Kamargaon Bazar & 18,500 & 18,550 & 18,600 & -- \\
\hline 27 & Tetia Bazar & 15,000 & 26,000 & 26,200 & -- \\
\hline
\end{tabular}


Table 3. Revenue earned from Scheduled Hat-Bazar Under Narayangonj Pourashava(Municipality)(Note 3, Note *)

\begin{tabular}{|l|l|l|l|l|l|l|l|l|}
\hline $\begin{array}{l}\text { Serial } \\
\text { No. }\end{array}$ & $\begin{array}{l}\text { Name of the } \\
\text { Hat-Bazar }\end{array}$ & Locality & $\begin{array}{l}\text { Income } \\
\text { in } 1407^{*} \\
\text { (taka) }\end{array}$ & $\begin{array}{l}\text { Income } \\
\text { in } 1408^{*} \\
\text { (taka) }\end{array}$ & $\begin{array}{l}\text { Income in } \\
1409 * \\
\text { (taka) }\end{array}$ & $\begin{array}{l}\text { Income in } \\
1410^{*} \\
\text { (taka) }\end{array}$ & $\begin{array}{l}\text { Income in } \\
1411^{*} \\
\text { (taka) }\end{array}$ & $\begin{array}{l}\text { Income in } 1412 * \\
\text { (taka) }\end{array}$ \\
\hline 1 & Digubabu Bazar & Municipality & $5,45,000$ & $6,05,000$ & $15,00,000$ & $10,25,000$ & $\begin{array}{l}14,21,500 \\
\text { Direct } \\
\text { Collection }\end{array}$ & Collection \\
\hline 2 & Kalir Bazar & Municipality & $1,08,001$ & $1,10,100$ & $1,78,500$ & $2,01,000$ & $2,36,100$ & $2,37,600$ \\
\hline 3 & $\begin{array}{l}\text { Bhagobangonj } \\
\text { Bazar }\end{array}$ & Municipality & $2,05,000$ & $2,22,000$ & $2,51,100$ & $2,60,000$ & $2,63,000$ & $2,65,000$ \\
\hline 4 & Godnail Bazar & Municipality & 54,000 & 55,000 & 56,000 & 56,800 & 57,100 & 61,500 \\
\hline
\end{tabular}

Table 4. Revenue earned from Scheduled Hat-Bazar Under Narayangonj Sadar Upazila (Note 3,Note *)

\begin{tabular}{|c|c|c|c|c|c|c|c|c|}
\hline \multirow{3}{*}{$\begin{array}{l}\text { Serial } \\
\text { No. }\end{array}$} & \multirow{3}{*}{$\begin{array}{l}\text { Name of the } \\
\text { Hat-Bazar }\end{array}$} & \multirow{3}{*}{ Locality } & \multicolumn{4}{|c|}{ Income in Income in Income in Income } & \multicolumn{2}{|c|}{ Income in Income in } \\
\hline & & & $1407 *$ & $1408 *$ & $1409 *$ & $1410 *$ & $1411 *$ & $1412 *$ \\
\hline & & & (Taka) & (Taka) & (Taka) & (Taka) & (Taka) & (Taka) \\
\hline 1 & $\begin{array}{l}\text { Fatulla } \\
\text { Hat-Bazar }\end{array}$ & Fatulla UP & $15,44,00$ & $19,31,000$ & $19,98,585$ & $35,00,000$ & $35,05,000$ & $51,00,000$ \\
\hline & Shiddhironi & Shiddhironi & & 66,790 & 48,093 & 47,695 & 35,255 & 24,375 \\
\hline 2 & Snidanirgonj & snidanirgonj & 85,200 & Direct & Direct & Direct & Direct & Direct \\
\hline & & IVtumterpanty & & Collection & Collection & Collection & Collection & Collection \\
\hline 3 & $\begin{array}{l}\text { DecreerChar } \\
\text { Hat-Bazar }\end{array}$ & Alirtek UP & 4,400 & 4,800 & 5,000 & 5,200 & 5,300 & 6,200 \\
\hline 4 & $\begin{array}{l}\text { Baktabali } \\
\text { Hat-Bazar }\end{array}$ & Baktabali UP & - & - & - & $1,05,555$ & $\begin{array}{l}3,375 \\
\text { Direct } \\
\text { Collection }\end{array}$ & $\begin{array}{l}3,215 \text { Direct } \\
\text { Collection }\end{array}$ \\
\hline
\end{tabular}

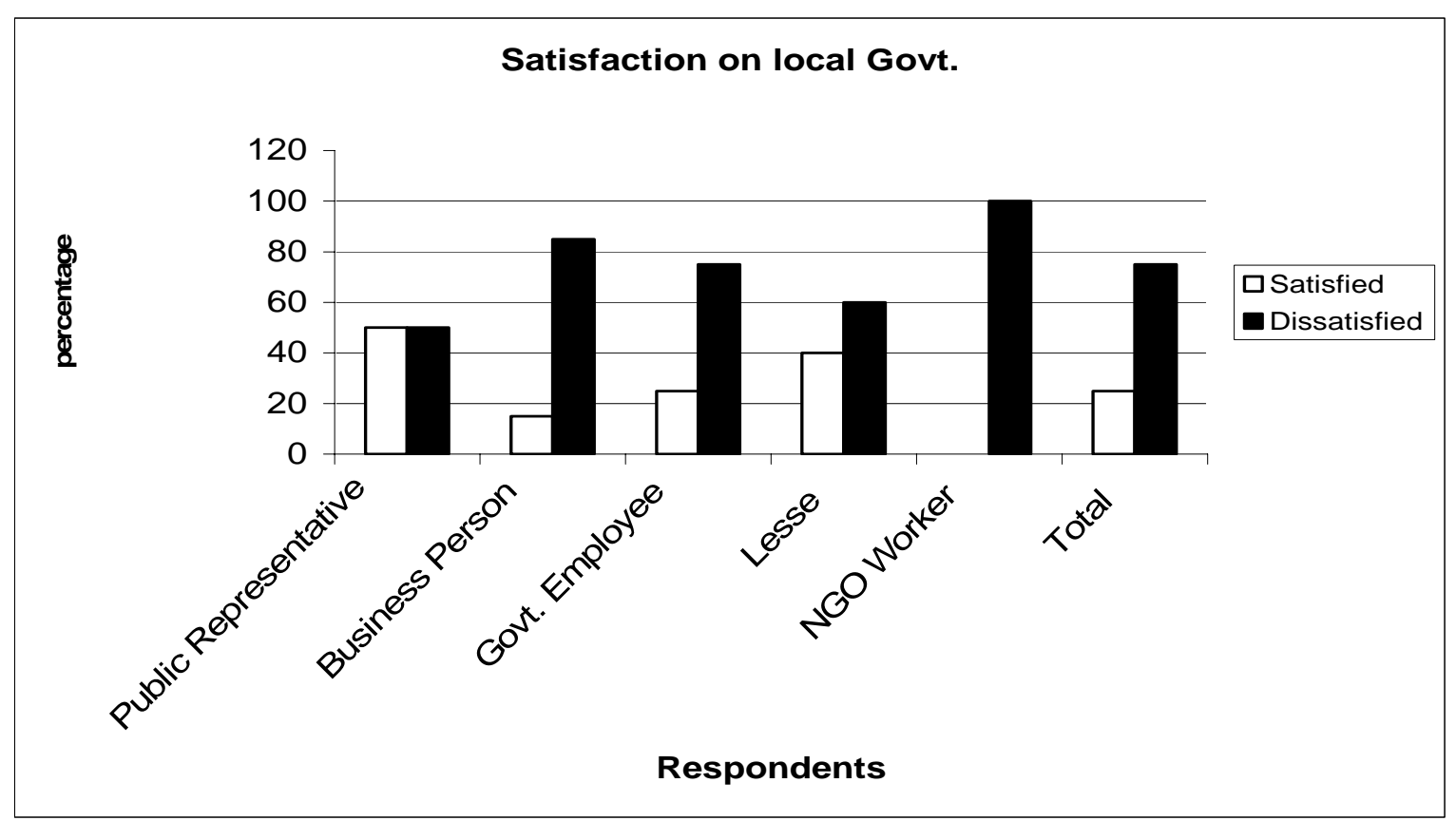

Figure 1. Responses on the satisfaction on the activities of the local Govt. 


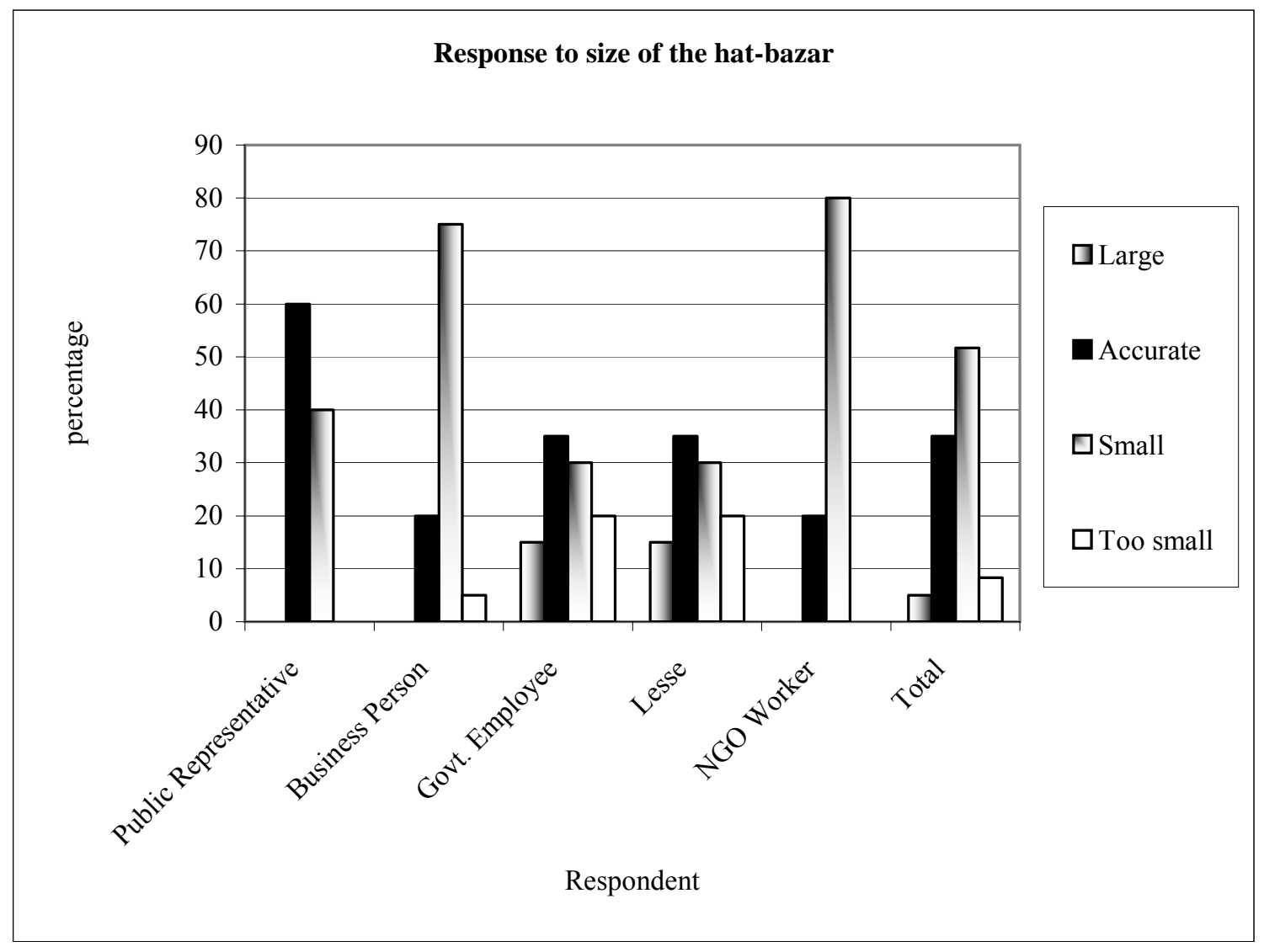

Figure 2. Responses to the size of the Hat-Bazar.

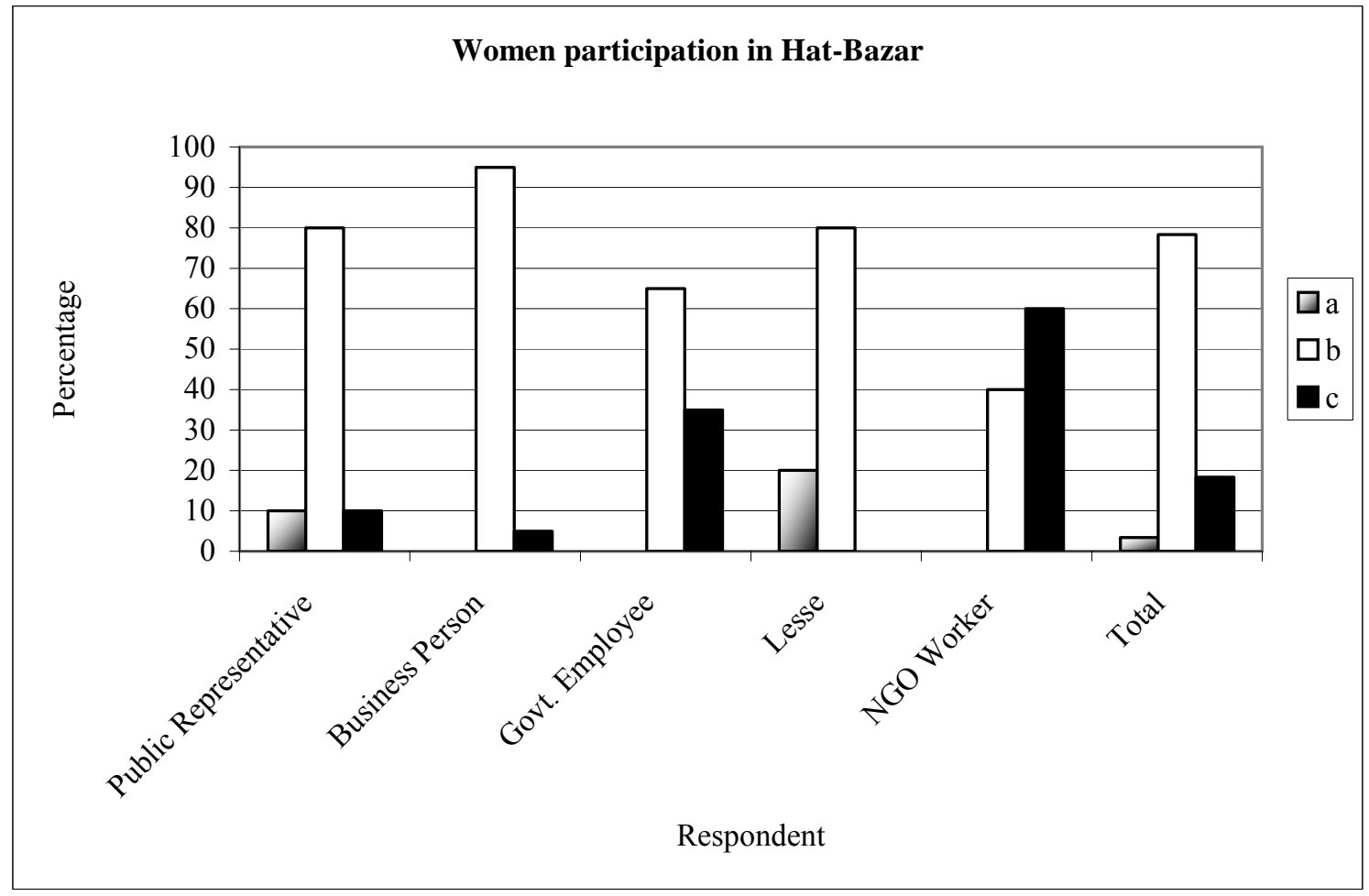

Figure 3. Responses on women participation in the Hat-Bazar. 


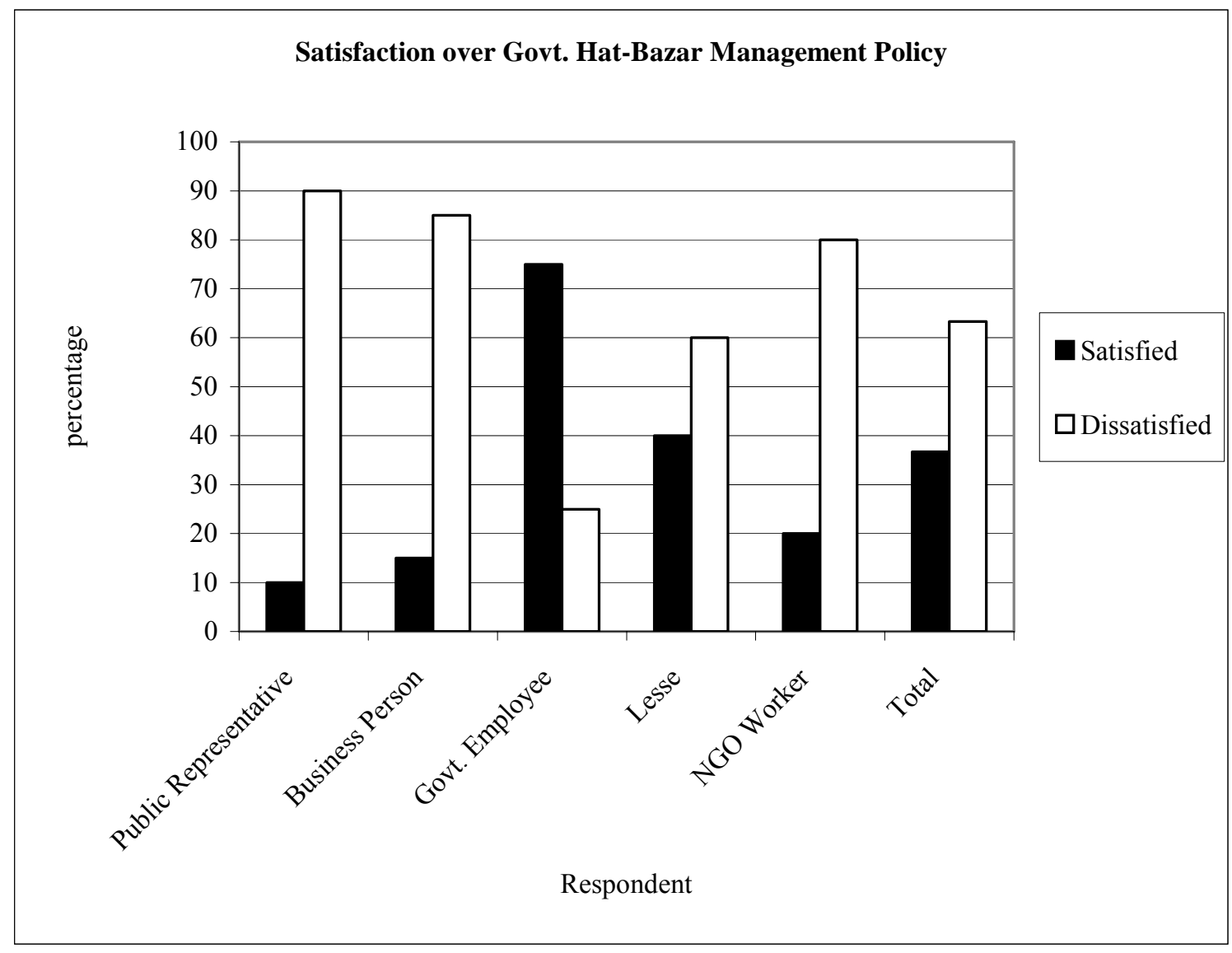

Figure 4. Responses on the satisfaction over the Hat-Bazar Management Policy.

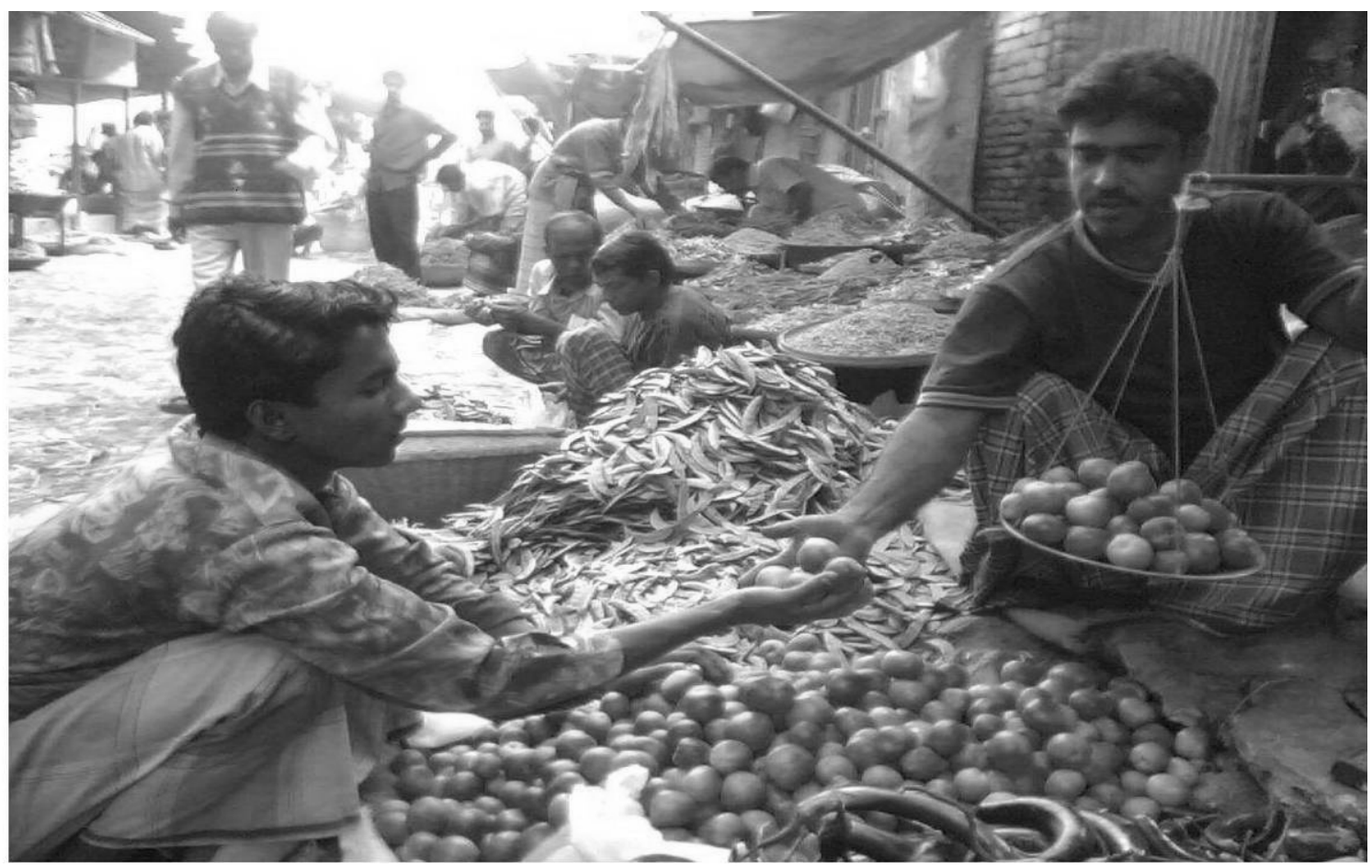

Figure 5. A view of a traditional Bazar (indigenous market) of Bangladesh. 